\title{
Investigation Barrier Properties of Linear Low Density Polyethylene (LLDPE) Spunbond Fabrics
}

\author{
Düşük Lineer Yoğunluklu Polietilen (LLDPE) Spunbond Kumaşların Bariyer Özelliklerinin \\ İncelenmesi
}

\author{
Esin SARIOĞLU ${ }^{1}{ }^{\mathbb{D}}$, Deniz VURUŞKAN ${ }^{1}$ \\ ${ }^{1}$ Gaziantep University, Faculty of Fine Arts, Department of Fashion and \\ Textile Design, Üniversite Bulvarl, 27310, Gaziantep, Türkiye
}

\begin{abstract}
Nonwovens have a growing worldwide market that has a vital proposition in many sectors such as geotextile, medical textile, automotive industry etc. which are supported by technological developments according to the desired characteristics. Among the production methods of the nonwovens, spunbond nonwovens made of polyprophylene (PP) have disposable and durable functional properties and are preferred especially in the field of disposable hygiene textiles. Although the fabric volume market of PP spunbond nonwovens is expected to grow rapidly owing to personal hygiene awareness with an increase in the aging population and regulations for hygiene, polyethylene spunbond nonwovens can probably share the application area due to having a lower melting point and easy processable. In this study, the effect of the weight of linear low density polyethylene (LLDPE) spunbond nonwovens on barrier properties such as resistance to air flow and water were evaluated. Results showed that weight has a statistically significant effect on air permeability and hydrostatic head pressure.
\end{abstract}

Keywords: Linear low density polyethylene, barrier properties, medical textile, spunbond, nonwoven.

Öz

İstenilen özelliklere gore teknolojik gelişmeler tarafından desteklenen jeotekstil, medikal tekstil, otomotiv endüstrisi gibi birçok sektörde hayati öneme sahip dokusuz kumaşlar dünya çapında büyüyen bir pazara sahiptir. Dokusuz kumaşların üretim metotları arasında polipropilen (PP) spunbond dokusuz kumaşlar tek kullanımlık ve dayanıklı fonksiyonel özelliklere sahiptir ve özellikle tek kullanımlık hijyen tekstilleri alanında tercih edilmektedir. Her ne kadar PP spunbond kumaş pazar hacminin yaşlanan nüfustaki artışı ve hijyen için gerçekleştirilen düzenlemelerle kişisel hijyen bilincinden dolayı hızlı bir şekilde büyümesi beklenirken, polietilen spunbond dokusuz kumaşlar sahip olduğu düşük erime noktası ve kolay ilenebilir olması nedeniyle uygulama alanını paylaşabilir. Bu çalışmada, düşük lineer yoğunluklu polietilen (LLDPE) spunbond dokusuz kumaşların kumaş ağırlıklarının hava ve su geçişine direnç gibi bariyer özellikleri üzerindeki etkisi değerlendirilmiştir. Sonuçlar, kumaş ağırlığının hava geçirgenliği ve hidrostatik su basıncı üzerinde istatistiksel olarak önemli bir etkisi olduğunu göstermiştir.

Anahtar Kelimeler: Düşük lineer yoğunluklu polietilen, bariyer özellikleri, medical tekstil, spunbond, dokusuz kumaş.

\section{INTRODUCTION}

Nonwoven fabrics are technical textiles manufactured using sheets or webs bonded via various thermal, chemical or mechanical processes. Such fabrics can be produced or modified to exhibit superior properties in accordance with the requirements of particular applications [1]. Nonwovens play an important role in the application of medical textiles. The use of PP as raw materials has a vital for hygiene and medical sector such as baby and adult diapers, medical products, feminine care etc. Figure 1 illustrates the PP nonwoven fabric market volume share in 2015 according to the product and application area. In this figure, PP spunbonded nonwovens have the highest production rates and hygiene and medical sectors have predominant volume and it is obvious that in these areas there are probably higher potential to investigate. 


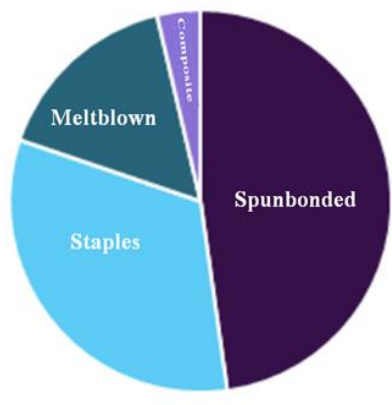

(a)

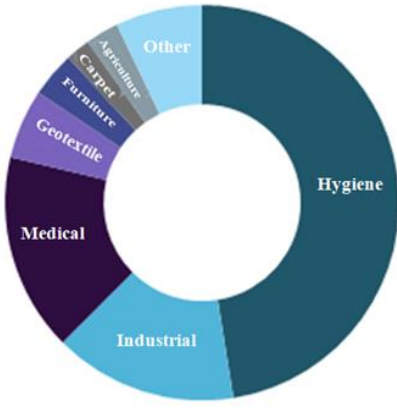

(b)
Figure 1. PP nonwoven fabric market volume share in 2015 (a) by product and (b) by application [2,3].

Polyethylene (PE) comes under the general category of polyolefins as the same as PP fiber and is also used in the nonwoven application. It can be classified as PE fibers into high density polyethylene (HDPE) and linear low density polyethylene (LLDPE). But there has been limited research on PE fibers [4]. Spunbond PE has an advantages that are lightweight, easy processing, good chemical resistance, good impact strength, excellent electrical properties, good barrier properties, low water absorption, toughness, and flexibility even at extremely low temperature, safe for food contact and non-toxic for skin contact, do not require pre-drying and recyclable [5]. Also, lower working temperature is needed than polypropylene polymer and LLDPE polymer has low moisture absorption rates [6] and it gives a softer fabric [7]. This study was focused on the evaluation of barrier properties in a different weight of LLDPE spunbonded nonwovens.

\section{MATERIAL AND METHOD}

In this study, LLDPE was chosen as the raw material of spunbonded nonwovens production because of the lower temperature necessary to processability than HDPE ones. The melt flow index of raw material was determined at $190^{\circ} \mathrm{C}$ temperature under $2.16 \mathrm{~kg}$ applying load as $11.6 \mathrm{~g} / 10$ min value. Nonwovens in different weight were manufactured in spunbond process which the schematic representation is shown in Figure 2.
Before the production, several trials were conducted to adapt the machine parameters for LLDPE spunbonded nonwoven. After these trials, optimum parameters were determined and the machine production settings as a range were given in Table 1.

Table 1. Main production settings.

\begin{tabular}{|l|c|}
\hline Production Settings & Value \\
\hline Extrusion Temperature, ${ }^{\circ} \mathbf{C}$ & $210-250$ \\
\hline Die Temperature, ${ }^{\circ} \mathbf{C}$ & $200-240$ \\
\hline Calendar Speed,m/min & $50-300$ \\
\hline Calendar Bonding Temperature, ${ }^{\circ} \mathbf{C}$ & 135 \\
\hline Nip Point Pressure, bar & $80-90$ \\
\hline
\end{tabular}

Before tests, LLDPE spunbonded nonwovens with 40 gsm, $50 \mathrm{gsm}, 60 \mathrm{gsm}, 80 \mathrm{gsm}$, and $100 \mathrm{gsm}$ weights were conditioned at $20 \pm 2{ }^{\circ} \mathrm{C}$ and $65 \pm 4 \%$ for 24 hours. The air permeability of samples was conducted according to the WSP 70.1 (05)-Standard Test Method for Air Permeability of Nonwoven Materials standard at $200 \mathrm{~Pa}$ pressure drop by using 20 $\mathrm{cm}^{2}$ test area by means of Sdl Atlas air permeability tester. Ten tests were performed for each sample and the mean results of air permeability in $\mathrm{mm} / \mathrm{sec}$ were evaluated. The hydrostatic pressure of samples was determined by means of Sdl Atlas hydrostatic head tester in accordance with WSP 80.6 (05) Standard Test Method for Evaluation of Water Resistance (Hydrostatic Pressure) Test standard. In this test, the rate of increase of water pressure was chosen as $60 \mathrm{cmH}_{2} \mathrm{O}$ / min by using $100 \mathrm{~cm}^{2}$ test head. Distilled water at $23 \pm 2^{\circ} \mathrm{C}$ temperature was used and tests were completed when three separate drops are formed on the different surface regions of the specimen. Five tests were performed for each sample. Hydrostatic pressure values were obtained as a $\mathrm{cmH}_{2} \mathrm{O}$ unit.

In order to evaluate the effect of weight on air permeability and hydrostatic pressure statistically, variance analysis was performed by means of the SPSS package program at a $95 \%$ confidence interval. Furthermore, the significant difference between weights was determined with post-hoc Tukey HSD multiple comparison test analysis.

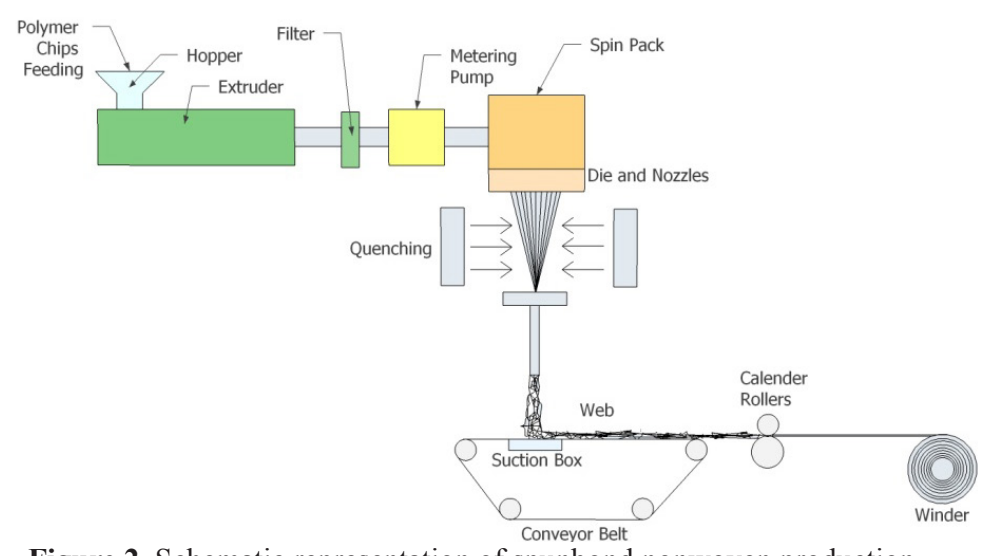

Figure 2. Schematic representation of spunbond nonwoven production. 


\section{RESULTS AND DISCUSSIONS}

The physical properties of LLDPE spunbonded nonwovens are given in Table 2.

Table 2. Physical properties of LLDPE spunbonded nonwovens.

\begin{tabular}{|l|l|l|}
\hline $\begin{array}{l}\text { LLDPE Spunbonded Nonwoven } \\
\text { Samples }\end{array}$ & $\begin{array}{l}\text { Thickness, } \\
\text { mm }\end{array}$ & $\begin{array}{l}\text { Weight, } \\
\text { gsm }\end{array}$ \\
\hline $\mathbf{4 0}$ & 0.30 & 40.3 \\
\hline $\mathbf{5 0}$ & 0.35 & 50.1 \\
\hline $\mathbf{6 0}$ & 0.41 & 61.3 \\
\hline $\mathbf{8 0}$ & 0.56 & 80.2 \\
\hline $\mathbf{1 0 0}$ & 0.67 & 101.1 \\
\hline
\end{tabular}

The air permeability of LLDPE spunbonded nonwovens was illustrated in Figure 3. It is obvious that an increase in the weight of the nonwovens affects the resistance to air flow positively by increasing the fiber volume within the nonwoven structure that prevents the air flow from the one side of the nonwoven to another. To produce the lower weight spunbonded nonwovens, changed machine settings affect the fiber thickness increase finally higher pore size arises. The best barrier property to air flow was obtained in 100 gsm LLDPE spunbonded nonwoven. The thickness of nonwovens also affects the air flow that is nonwoven with higher thickness show higher resistance.

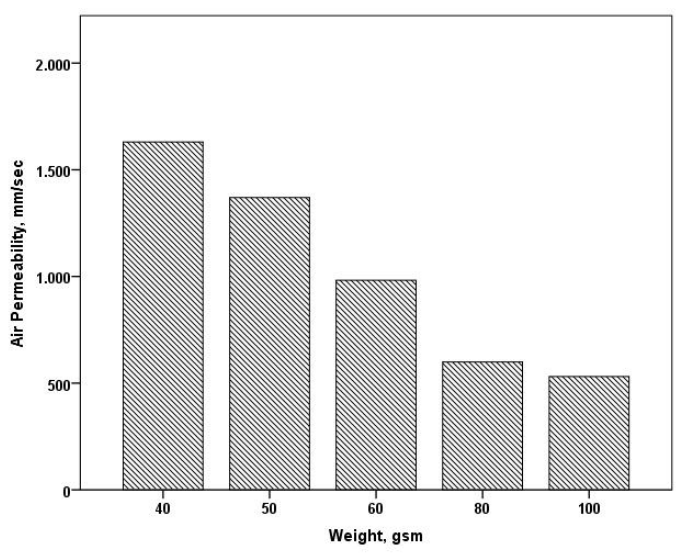

Figure 3. Air permeability of LLDPE spunbonded nonwovens.
The resistance to the water of nonwoven samples is shown in Figure 4. Hydrostatic pressure in $\mathrm{cmH}_{2} \mathrm{O}$ of LLDPE spunbonded nonwovens shifts positively from lower weight to higher one that makes the nonwoven more resistance to water pressure. It can be said that $40 \mathrm{gsm}$, $50 \mathrm{gsm}$ and $60 \mathrm{gsm}$ of LLDPE spunbonded nonwovens show similar resistance to water pressure because of the lower or 10 gsm differences between these nonwovens. On the other hand, resistance to the water pressure of $60 \mathrm{gsm}$ is lower than 50 gsm nonwoven but the difference is low so it can be ignored. When 80 gsm and 100 gsm nonwovens hydrostatic pressure are taken into consideration, these are also similar resistance and higher than that of three ones. Thickness and weight of the nonwovens are related to each other that make the nonwoven more compact and have a lower pore size. Under the pressure, water can easily come out to the surface of the nonwoven with higher pore size.

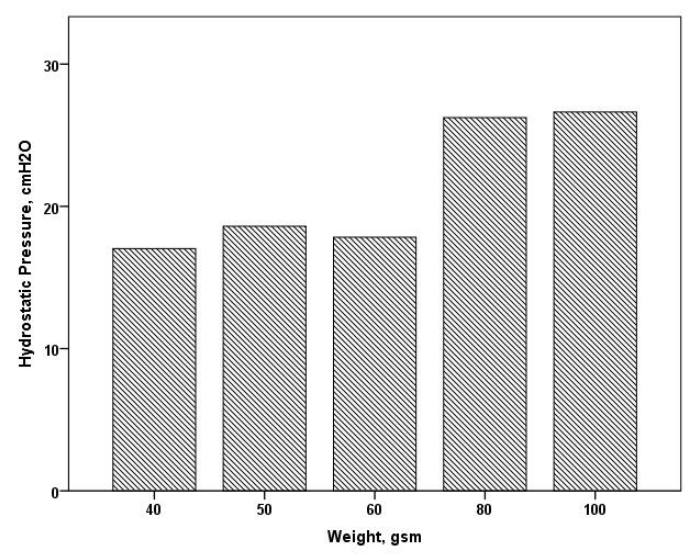

Figure 4. Hydrostatic pressure of LLDPE spunbonded nonwovens.

Statistical analysis results were shown in Table 3. According to the analysis of variance results, the effect of weight on air permeability was found to be statistically significant with $p<0.001$. The analysis explains about $97.8 \%$ of the variability in air permeability for all nonwovens. Besides, weight has also statistically significant $(p<0.001)$ effect on hydrostatic pressure and adjusted $\mathrm{R}^{2}$ was determined as $94 \%$ with a very high value. 
Table 3. Analysis of variance of LLDPE spunbonded nonwovens with different weight.

\begin{tabular}{|c|c|c|c|c|c|c|c|}
\hline Source & Dependent Variable & Type III Sum of Squares & df & Mean Square & $\mathbf{F}$ & Sig. & $\begin{array}{c}\text { Partial Eta } \\
\text { Squared }\end{array}$ \\
\hline \multirow{2}{*}{$\begin{array}{c}\text { Corrected } \\
\text { Model }\end{array}$} & Air permeability & $2890140.933^{\mathrm{a}}$ & 4 & 722535.233 & 158.402 & 0.000 & 0.984 \\
\hline & Hydrostatic pressure & $270.867^{\mathrm{b}}$ & 4 & 67.717 & 55.658 & 0.000 & 0.957 \\
\hline \multirow[t]{2}{*}{ Intercept } & Air permeability & 16159584.067 & 1 & 16159584.067 & 3542.681 & 0.000 & 0.997 \\
\hline & Hydrostatic pressure & 6784.067 & 1 & 6784.067 & 5575.945 & 0.000 & 0.998 \\
\hline \multirow[t]{2}{*}{ Weight } & Air permeability & 2890140.933 & 4 & 722535.233 & 158.402 & 0.000 & 0.984 \\
\hline & Hydrostatic pressure & 270.867 & 4 & 67.717 & 55.658 & 0.000 & 0.957 \\
\hline \multirow[t]{2}{*}{ Error } & Air permeability & 45614.000 & 10 & 4561.400 & & & \\
\hline & Hydrostatic pressure & 12.167 & 10 & 1.217 & & & \\
\hline \multirow[t]{2}{*}{ Total } & Air permeability & 19095339.000 & 15 & & & & \\
\hline & Hydrostatic pressure & 7067.100 & 15 & & & & \\
\hline \multirow{2}{*}{$\begin{array}{c}\text { Corrected } \\
\text { Total } \\
\end{array}$} & Air permeability & 2935754.933 & 14 & & & & \\
\hline & Hydrostatic pressure & 283.033 & 14 & & & & \\
\hline \multicolumn{8}{|c|}{ a. R Squared $=0.984$ (Adjusted R Squared $=0.978$ ) } \\
\hline \multicolumn{8}{|c|}{ b. R Squared $=0.957$ (Adjusted R Squared $=0.940)$} \\
\hline
\end{tabular}

Table 4 displays the Tukey HSD multiple comparison results of LLDPE spunbonded nonwovens. It can be said that there is no difference between of air permeability of $80 \mathrm{gsm}$ and 100 gsm nonwovens. From 100 gsm to 40 gsm nonwovens air permeability increases. The highest air permeability was obtained from 40 gsm nonwoven with high pore size. In Table 5, Tukey HSD multiple comparison results show that there is no such difference between $40 \mathrm{gsm}, 50 \mathrm{gsm}$ and $60 \mathrm{gsm}$ nonwovens for hydrostatic pressure. Likewise, $80 \mathrm{gsm}$ and $100 \mathrm{gsm}$ nonwovens were found as the same.

Table 4. Tukey HSD multiple comparison for air permeability.

\begin{tabular}{|c|c|c|c|c|}
\hline \multirow{2}{*}{$\begin{array}{c}\text { Weight, } \\
\mathbf{g s m}\end{array}$} & $\mathbf{1}$ & $\mathbf{2}$ & $\mathbf{3}$ & $\mathbf{4}$ \\
\hline $\mathbf{1 0 0}$ & 548.33 & & & \\
\hline $\mathbf{8 0}$ & 587.67 & & & \\
\hline $\mathbf{6 0}$ & & 997.00 & & \\
\hline $\mathbf{5 0}$ & & & 1390.00 & \\
\hline $\mathbf{4 0}$ & & & & 1666.67 \\
\hline Sig. & 0.949 & 1.000 & 1.000 & 1.000 \\
\hline \\
The error term is Mean Square(Error) $=4561.400$. \\
\hline \\
Uses Harmonic Mean Sample Size $=3.000$. \\
\hline Alpha $=0.05$. \\
\hline
\end{tabular}

Table 5. Tukey HSD multiple comparison for hydrostatic pressure.

\begin{tabular}{|c|c|c|}
\hline \multirow{2}{*}{$\begin{array}{c}\text { Weight, } \\
\text { gsm }\end{array}$} & $\mathbf{1}$ & Subset \\
\hline $\mathbf{4 0}$ & 17.033 & $\mathbf{2}$ \\
\hline $\mathbf{6 0}$ & 17.833 & \\
\hline $\mathbf{5 0}$ & 18.600 & \\
\hline $\mathbf{8 0}$ & & 26.233 \\
\hline $\mathbf{1 0 0}$ & 0.454 & 26.633 \\
\hline Sig. & & 0.991 \\
\hline \multicolumn{2}{|c|}{} \\
\hline The error term is Mean Square(Error) $=1.217$. \\
\hline Uses Harmonic Mean Sample Size $=3.000$. \\
\hline Alpha $=0.05$. \\
\hline
\end{tabular}

\section{CONCLUSIONS}

As a conclusion, LLDPE spunbonded nonwovens are easily used with an alternative to the PP spunbonded nonwovens when required properties obtained according to the application areas. In the medical sector, when talking about the surgical clothes these nonwovens can be used with softer fabric properties which makes it more comfortable especially than PP spunbonded nonwoven. With optimum machine settings, LLDPE spunbonded nonwovens can be easily produced. This study was evaluated the barrier properties of LLDPE spunbonded nonwovens against air flow and water pressure. Thus, five weight types of spunbonded nonwovens were produced as one layer. Results showed the effect of the weight on air permeability and hydrostatic pressure was found to be statistically significant.

For further study, it is planned to investigate the LLDPE spunbonded nonwovens with LLDPE film coating at different production parameters. Besides, PP spunbonded nonwovens with LLDPE film coating will be also manufactured in order to compare the properties.

\section{Acknowledgements}

This research was supported by Bayteks Teknik Tekstil Company and all sample production was held in this company which is located in Kilis/Turkey. The authors would like to thank Gökhan Selçuk Gerlikhan and his team for their contribution to this study. The authors would also thank Süper Film Packaging Company for their test analysis contribution. 


\section{REFERENCES}

[1] Cheema, S.M., Shah, T.H., Anand, S.C. and Soin, N. (2018). Development and characterisation of nonwoven fabrics for apparel applications. J. Textile Sci. Eng., 8(3), 1-7.

[2] Polypropylene (PP) Nonwoven Fabric Market Size, Share \& Trends Analysis Report By Application (Hygiene, Medical, Furnishings, Geotextiles), By Product (Meltblown, Staple, Spunbonded), And Segment Forecasts, 2019 - 2025, https:// www.grandviewresearch.com/industry-analysis/polypropylene-nonwoven - fabric-market, (March 2019).

[3] PP (Polypropylene) Nonwoven, A versatile fabric, https://www.grandviewresearch.com/blog/pp - polypropylene-nonwoven-fabric-market-size-share, (February 2019).

[4] Mukhopadhyay, S. (2014). Natural and synthetic fibres for composite nonwovens. In: Composite nonwoven materials-structure, properties and applications, D. Das and B. Pourdeyhimi (ed.), 1. Edition, Woodhead Publishing, United Kingdom, p.22-23.

[5] Spunbonded Polyethylene, http://www.techtex.co.uk/industrial/products/non-woven/spunbonded - polyethylene, (March 2019).

[6] Yeşil, Y. and Bhat, G.S. (2016). Structure and mechanical properties of polyethylene melt blown nonwovens. International Journal of Clothing Science and Technology, 28 (6), 780-793.

[7] Bhat, G.S. and Malkan, S.R. (2007). Polymer-laid web formation. In: Handbook of nonwovens, S.J. Russell (ed.), 1. Edition, Woodhead Publishing, Cambridge, England, p.168169. 